Mеталлофиз. новейшие технол. / Metallofiz. Noveishie Tekhnol. (c) 2017 ИМФ (Институт металлофизики 2017 , т. 39, № 8, сc. 1129-1148 / DOI: 10.15407/mfint.39.08.1129 им. Г. В. Курдюмова НАН Украины) Оттиски доступны непосредственно от издателя

Фотокопирование разрешено только

Напечатано в Украине.

в соответствии с лицензией

PACS numbers: 05.65.+b, 62.20.de, 68.35.Dv, 68.35.Gy, 68.35.Md, 68.55.J-, 81.40.Jj

\title{
Deformation-Induced Interfacial Interaction in Elastically-Plastically Deformed Single Crystals of $\mathrm{Cd}_{x} \mathrm{Hg}_{1-x} \mathrm{Te}$
}

\section{B. P. Koman}

Ivan Franko National University of Lviv, Faculty of Electronics and Computer Technologies, 1 Universytetska Str.,

UA-79000 Lviv, Ukraine

In this paper, features of deformation-induced interfacial interaction in uniaxial loaded crystals and its contribution to the formation of a stressedly plastic state are analysed. As found, the uniaxial deformed crystal is a complex structure including the following interphase-interacting elements: 1) the 'debris'-layer, which is formed in the previous stage of pseudo-elastic deformation in the crystal surface region, and the bulk of a crystal; 2) the locally fragmented cells within the bulk of a crystal, which are disoriented at certain angles relatively to each other and characterized by different Young's moduli $E_{1}, \ldots, E_{n}$. The behaviour of loading diagram is determined by interaction of the two types: between the 'debris'-layer, which has the highest Young's modulus, and the bulk of deformed crystal as well as directly between the local cells in the bulk of fragmented structure of a crystal. In deformed $\mathrm{Cd}_{x} \mathrm{Hg}_{1-x} \mathrm{Te}$ crystals, new types of dissipative structures are revealed. The energy parameters of interfacial interactions caused by mechanical incompatibility of adjoining regions and their correlation with the rate of strain hardening $\theta$ at its stage $L_{2}$ are estimated.

Key words: interfacial interaction, deformation, deformation fragments, Young's modulus, dissipation.

У праці з'ясовано закономірності формування деформаційно-індукованої міжфазової взаємодії в одновісно навантажених кристалах і внесок цього

Corresponding author: Bohdan Petrovych Koman

E-mail: sonce_28@ukr.net

Please cite this article as: B. P. Koman, Deformation-Induced Interfacial Interaction in Elastically-Plastically Deformed Single Crystals of $\mathrm{Cd}_{x} \mathrm{Hg}_{1_{-x}} \mathrm{Te}$, Metallofiz.

Noveishie Tekhnol., 39, No. 8: 1129-1148 (2017), DOI: 10.15407/mfint.39.08.1129. 
механізму у формування напружено-пластичного стану. Встановлено, що одновісно деформований кристал є складною структурою, яка включає наступні міжфазово взаємодійні елементи: 1) «debris»-шар, сформований на попередній псевдопружній стадії деформації у приповерхневих областях кристалу, та об’єм кристалу; 2) локально фраг'ментовані комірки у межах об'єму кристалу, дезорієнтовані одна відносно одної на певні кути та з різними модулями Юнґа $E_{1}, \ldots, E_{n}$. Поведінка діяграми навантаження визначається міжфазовою взаємодією двох типів: між «debris»-шаром, який має найвищий модуль Юнга, та об’ємом деформованого кристалу, а також безпосередньо між локальними комірками фрагментованої структури в об'ємі кристалу. В деформованих кристалах $\mathrm{Cd}_{x} \mathrm{Hg}_{1-x}$ Те виявлено нові типи дисипативних структур. Проведено оцінювання енергетичних параметрів міжфазової взаємодії, зумовленої механічною несумісністю сусідніх областей, та їх кореляції з коефіцієнтом деформаційного зміцнення $\theta$ на стадії деформаційного зміцнення $L_{2}$.

Ключові слова: міжфазова взаємодія, деформація, деформаційні фрагменти, модуль Юнґа, дисипація.

В работе установлены закономерности формирования деформационноиндуцированного взаимодействия в одноосно нагружённых кристаллах и вклад этого механизма в формирование напряжённо-пластического состояния. Установлено, что одноосно деформируемый кристалл является сложной структурой, включающей следующие межфазно взаимодействующие элементы: 1) «debris»-слой, сформированный на предыдущей псевдоупругой стадии деформирования в приповерхностных областях кристалла, и объём кристалла; 2) локально фрагментированные ячейки в пределах объёма кристалла, разориентированные одна относительно другой на определённые углы и обладающие различными модулями Юнга $E_{1}, \ldots, E_{n}$. Поведение диаграммы нагружения определяется межфазным взаимодействием двух типов: между «debris»-слоем, обладающим наивысшим модулем Юнга, и объёмом деформированного кристалла, а также непосредственно между локальными ячейками фрагментированной структуры в объёме кристалла. В деформированных кристаллах $\mathrm{Cd}_{x} \mathrm{Hg}_{1-x}$ Te обнаружены новые типы диссипативных структур. Проведена оценка энергетических параметров межфазного взаимодействия, обусловленного механической несовместимостью соседних областей, и их корреляции с коэффициентом деформационного упрочнения $\theta$ на стадии деформационного упрочнения $L_{2}$.

Ключевые слова: межфазное взаимодействие, деформация, деформационные фрагменты, модуль Юнга, диссипация.

(Received November 14, 2016; in final version, August 13, 2017 )

\section{INTRODUCTION}

Modern investigations of plasticity carried out on the example of $\mathrm{Cu}$, $\mathrm{Si}, \mathrm{Ge}, \mathrm{NaCl}$ crystals have shown that deformation of crystals is ac- 
companied by intensive dissipation of energy on all structural levels with forming the local deformation-fragmented structures. They are divided by dislocation boundaries and have substantially different physical-mechanical properties [1, 2]. However, by now, their contribution to the deformation process has been not established. In addition, the carried out studies have not given sufficient information about the peculiarities of behaviour of surface layers at different scale levels of deformation, what is an especially topical issue for structures of micro- and nanoelectronics.

At the same time, the space-time heterogeneity of the processes of inelastic deformation with the participation of local fragments and interphase interaction between them are observed in metals. These features can be considered as an important aspect for understanding of the mechanisms of plastic strengthening and its stage nature [3-6], in particular the mechanisms of formation of the curves of the deformation strengthening 'stress-deformation' $\sigma-\varepsilon$ in microhomogeneous systems of the metallic alloy type. In such objects, the plastic deformation can be accompanied by a local (in a range of $10 \mathrm{~nm}$ [7]) change in the composition in the stripes of the displacement localization caused by atomic mixing.

As a result, even the process of quasi-periodic homogenization can be realized in the system under consideration that has been observed, for example, in aluminium-magnesium alloys [8].

Therefore, the deformation strengthening of such materials cannot be explained exclusively by the dislocation mechanisms [9]. Obviously, it should be taken into account that in a non-equilibrium system of this type (deformed crystal) there are self-organizing processes, which lead to decreasing the entropy [10] due to fragmentation of the structure.

The consequence of these processes is appearance in a deformed object of the local structures with different types of structural ordering, which are separated by phase boundaries and possess different Young's modules. Interphase interaction between these structures will cause mechanical stress at their boundaries. In polycrystalline objects, such an interaction is realized between separate grains due to their crystallographic disorientation. It is clear that the contribution of dislocation and non-dislocation mechanisms at different stages of the deformation strengthening of the crystal will be different. Thus, the deformation process of such complex objects should be considered from the viewpoint of multilevel hierarchy of organized systems, which are realized at its various stages.

Therefore, the aim of this paper is to establish the role of interfacial interactions with participation of deformation fragments in the formation of an elastic-plastic state in semiconductor crystals at different structural levels of their deformation as well as in the transformation of defect-impurity structure of the surface layers. 


\section{EXPERIMENTAL RESULTS AND THEIR DISCUSSION}

\subsection{The Objects and Methods of Research}

The objects for the research were intrinsically defective crystals CdTe, $\mathrm{HgTe}$ and their solid solutions $\mathrm{Cd}_{x} \mathrm{Hg}_{1-x} \mathrm{Te}$ of semiconductor composition $(x=0.16-0.22)$ grown by the Bridgman method and solid state recrystallization as well as crystals $\mathrm{Si}, \mathrm{Ge}, \mathrm{NaCl}$ grown by the Czochralski and Stockbarger methods. Deformation measurements were carried on Regel-Dubov relaxometer with registration of loading curves 'stress-strain' $(\sigma-\varepsilon)$. Deformation of the samples $\left(2 \times 2 \times 6 \mathrm{~mm}^{3}\right)$ was performed along the longer edge at a constant rate. The rate of deformation was chosen in the range $2 \cdot 10^{-6}-9 \cdot 10^{-5} \mathrm{~s}^{-1}$. Microhardness measurements were made by standard methods on a device PMT-3. Simultaneous measurement of the Hall coefficient during deformation was performed in a constant magnetic field with induction of $0.8 \mathrm{~T}$. Measurements of electrical conductivity $\sigma_{0}$ were carried out in DC mode with using the standard four-probe technique.

\subsection{Formation of a Defect-Gradient Layer in the Surface Region of Uniaxial Deformed Crystals $\mathrm{Cd}_{x} \mathrm{Hg}_{1-x} \mathrm{Te}$}

As a result of a number of studies, it has been found that the initial acts of plastic fluidity are usually associated with surface layers. Direct structural studies on single crystals of $\mathrm{Fe}, \mathrm{Al}, \mathrm{Cu}$ and $\mathrm{LiF}, \mathrm{KCl}$ have showed that the behaviour of the surface layer at deformation significantly differs from that of internal layers of bulk material, and the features of microplastic deformation of the surface layers influence the course of the curve of deformation hardening $\sigma-\varepsilon[1,2]$.

It is known that semiconductor crystals by uniaxial load at a constant speed are characterized by the four-stage deformation curve $\sigma-\varepsilon$, typical for the face-centred metals, with a characteristic 'tooth' after pseudo-elastic stage $[1,11]$. This feature is caused by the weakened conditions of the origin and movement of dislocations in the surface layer of the loaded crystal and subsequent barrier effect of the 'debris'layer for the dislocations that come to the surface.

In this context, let us examine the properties of such layer and elastic-plastic behaviour of the system 'debris'-layer-bulk of crystal during the uniaxial compression.

For clarifying the problem of specific contribution of the barrier action of 'debris'-layer to the formation of a fluidity 'tooth' at simultaneous action of other mechanisms, we have carried out experiment according to the Kramer's technique [1]: the deformed surface layer was etched during loading the sample. The samples of series that showed the primary 'tooth' were uniaxial deformed with registration of $\sigma-\varepsilon$ 
diagram. Loading the first sample was carried out in normal conditions. Deformation of two others is carried out in the solution of bromine in methanol. The rate $W$ of removing the surface layer was regulated by the concentration of etchant. The experimental results are presented in Fig. 1.

It is seen that such layer has the standard loading curve with a fluidity 'tooth'. Deformation of the second sample in the solution, which provides a surface-layer etching rate of $3 \mu \mathrm{m} / \mathrm{min}$, is accompanied by a decrease in the 'tooth'. At loading in the $10 \%$ etchant $(W=6 \mu \mathrm{m} / \mathrm{min})$, the primary 'tooth' is not observed. Thus, elimination of the reason, which opposes moving the dislocations to the crystal surface, substantially changes the kinetics of deformation hardening of the crystal.

This layer possesses the increased microhardness due to strengthening the lattice dislocations of 'forest' and excessive concentration of point defects. Layer-by-layer etching of such layer rapidly and linearly decreases the microhardness at the expense of reducing the concentration of these defects, reaching the saturation at total etching of the 'debris'-layer, i.e. after reaching the bulk of the crystal (Fig. 2). It is seen that a peculiarity of the behaviour of the dependences of microhardness on the thickness of etched layer $H V(d)$ in the samples under study is the difference in their behaviour for crystals of different stoichiometry due to the features of movement and breeding of dislocations.

The increased dislocation density near the surface of the crystal increases short- and long-range components of internal stresses. Therefore, the common used equation that describes the rate of plastic de-

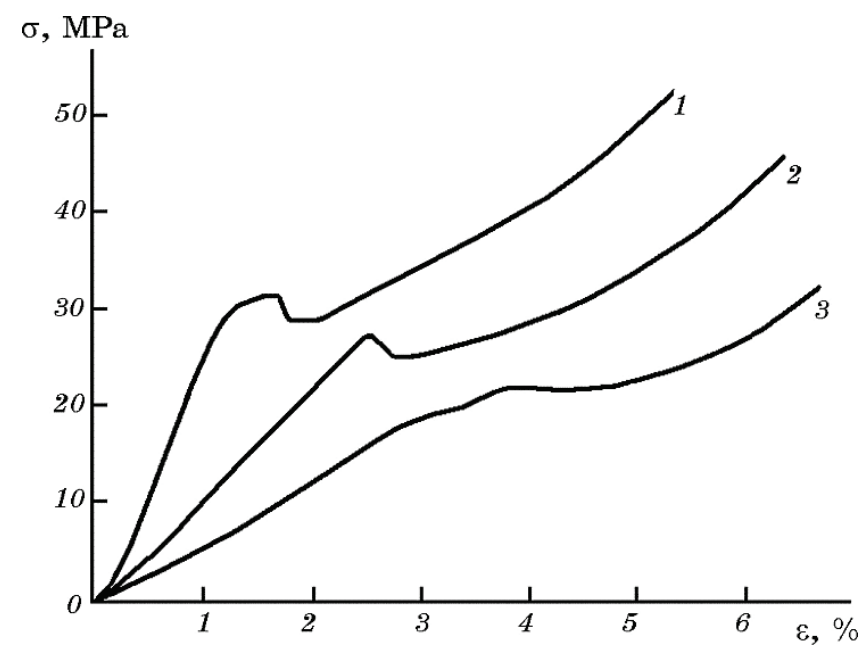

Fig. 1. Loading curves $\sigma-\varepsilon$ of $\mathrm{Cd}_{0.2} \mathrm{Hg}_{0.8}$ Te crystals in different conditions: $1-$ deformation in the air, $T=290 \mathrm{~K} ; 2-5 \%$ solution of bromine in methanol; $3-10 \%$ solution of bromine in methanol. 
formation must be added by the additional term $\sigma$, which takes into account the barrier effect of the surface gradient of the dislocation density:

$$
\dot{\varepsilon}=\dot{\varepsilon}_{0} \exp \left[-\frac{U-q\left(\sigma_{a}-\sigma_{i}-\sigma_{s}\right)}{k T}\right],
$$

where $\sigma_{i}=\alpha G b \sqrt{N}, \sigma_{a}$-external applied stress, $\sigma_{i}$-internal pressure as a result of plastic deformation surround layers of material, $\sigma_{s}-$ similar, to the value of internal stress that created 'debris'-layer.

Obviously, if the near-surface gradient layer is removed and thus the additional barrier is eliminated, therefore, according to equation (1), one should observe the corresponding increasing the activation volume $q$ and lowering the activation energy of plastic deformation $U$, what is demonstrated in the experiment (Fig. 3). The activation energy was calculated on the basis of measurement of the temperature dependence of microhardness $H V(T)$ by the Trefilov-Milman technique [12, 13] for five samples from the same series exposed to the same deformation after etching the near-surface layer of the respective thickness.

Figure 3 shows the results of such research. To determine the activation volume at different depths of etching of surface layer, we used the

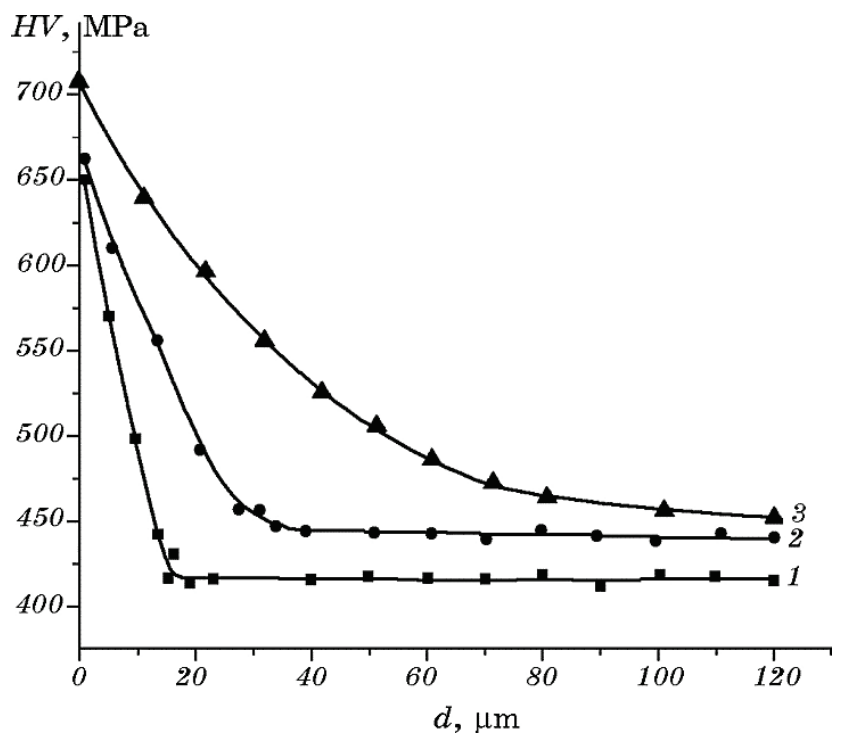

Fig. 2. Change in the microhardness of $\mathrm{Cd}_{x} \mathrm{Hg}_{1-x} \mathrm{Te}(x=0.2)$ crystals of different stoichiometry in the direction from the surface at successive etching of the surface layer after preliminary deformation: $1-\varepsilon=0.8 \%, n$-type, carrier concentration $n_{77}=10^{16} \mathrm{~cm}^{-3} ; 2-\varepsilon=0.8 \%, p_{77}=3 \cdot 10^{17} \mathrm{~cm}^{-3} ; 3-\varepsilon=1.8 \%, n_{77}=$ $=8 \cdot 10^{15} \mathrm{~cm}^{-3}$. 
method of abrupt change of speed during the process of deformation [14]. Thus, as can be seen, depending on the 'debris'-layer thickness the range of obstacles to the movement of dislocations undergoes significant changes, however, it is obvious the fact of increasing the crystal structural perfection in the direction to the crystal bulk. That is, all the deformed crystal bulk behaves itself as if being placed in a rigid shell of the near-surface layer, reinforced by the increased density of net of dislocations and concentration of point defects.

Existence of the 'debris'-layer is confirmed by the patterns of dislocation etching which show the layer with high density of dislocations after preliminary deformation of the crystal below the fluidity limit.

Comparison of the diagram of loading and simultaneous measurements of Hall coefficient $R_{H}(\varepsilon)$, conductivity $\sigma_{0}(\varepsilon)$ shows that the final time of formation of the final 'debris'-layer is determined by the characteristic points on the synchronous dependences with deformation $R_{H}(\varepsilon)$ and $\sigma_{0}(\varepsilon)$ and corresponds to the degree of strain $\varepsilon_{0}$ (fluidity 'tooth') (Fig. 4). This evidences in favour of sharp difference between the nature of deformation processes at the stage of 'debris'-layer crystal and in the conditions of transition of the crystal to the stage of strain hardening.

Significant changes in the electrical conductivity of the samples occur after reaching the 'tooth' of fluidity. So, at the stage of defor-

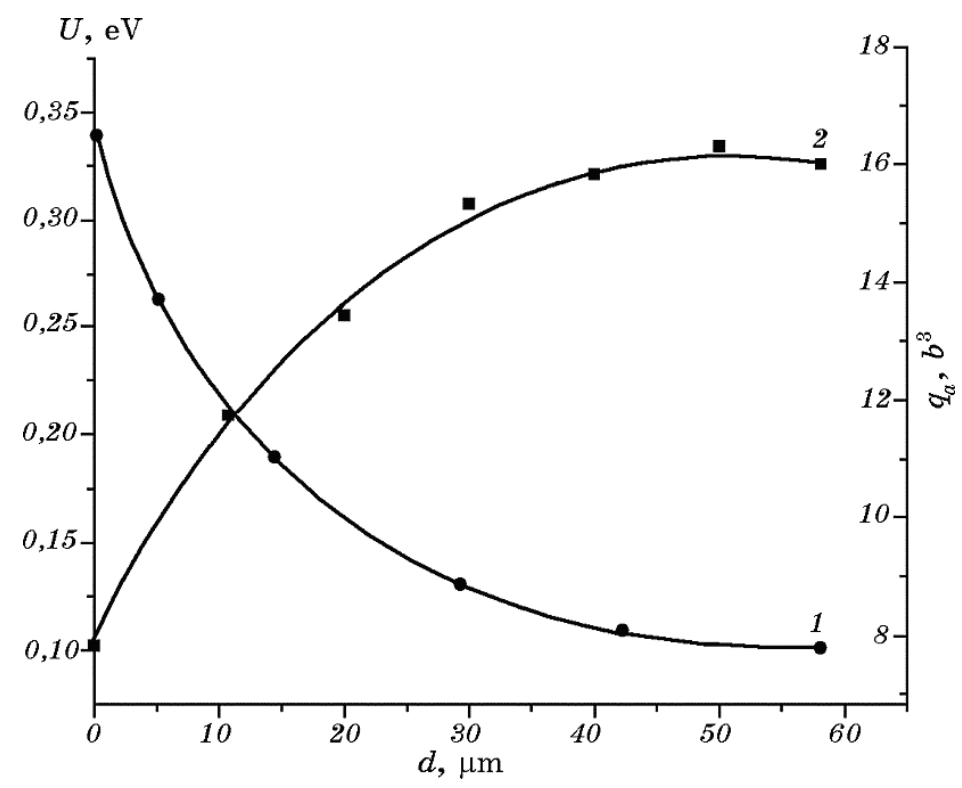

Fig. 3. Change in the activation energy of plastic deformation $U$ and activation volume of dislocation motion $q_{a}$ in $n-\mathrm{Cd}_{x} \mathrm{Hg}_{1-x} \mathrm{Te}(x=0.2)$ crystals at successive etching of 'debris'-layer, $T=300 \mathrm{~K}$. 
mation before the 'tooth' $\left(\varepsilon<\varepsilon_{0}\right)$, the electrical changes are caused by the processes responsible for formation of the 'debris'-layer. Transition of the deformation process to the stage macrofluidity (above $\varepsilon_{0}$ ) is accompanied by delocalization of the processes of defect formation, i.e. involvement of the bulk of the crystal in the deformation process. Accordingly, changes in the electrical parameters during deformation at this stage are caused that occur in the 'internal' crystal modified with respect to the initial sample.

Thus, the presented results show that the defect structure on the surface of the real crystal does not reflect the processes taking place in the bulk of the crystal. In this respect, if the near-surface gradient of dislocation density is regarded as one of the forms of heterogeneity of microplastic deformation, the deformed crystal on the stage of pseudoelastic deformation before the 'fluidity tooth' is a heterostructure of the 'debris'-layer-bulk of crystal type. That is, the deformed crystal before the 'fluidity tooth' presents a structure consisting of two different adjacent materials (phases), which have different physical and mechanical parameters, including the Young's moduli. Therefore, the deformation kinetics of the crystal at this stage is determined mainly by the dislocation processes in the 'debris'-layer and interfacial interaction in the set of 'debris'-layer-bulk of crystal. The first aspect of this problem was thoroughly investigated by us in work [11].

In general, this type of interaction occurs due to physicochemical, thermodynamic and mechanical incompatibility of interacting phases. Energy parameters of the interfacial interaction (energy of interfacial interaction and interfacial tension) quantitatively determine the character of this interaction, the level of internal stresses and value of interfacial charge. In the deformed crystal, the interfacial interaction

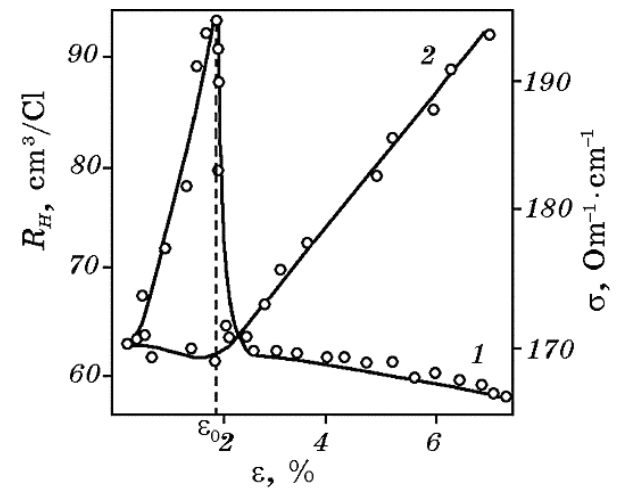

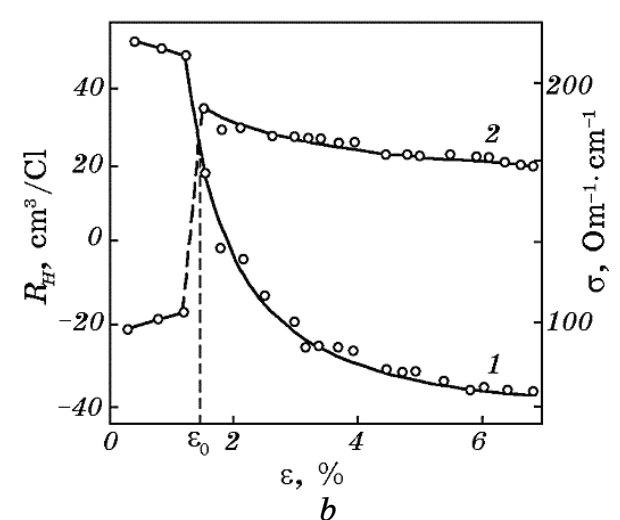

Fig. 4. Change in the Hall coefficient (1) and electrical conductivity (2) during the process of uniaxial deformation $(T=300 \mathrm{~K})$ of crystals $n-\mathrm{Cd}_{0.2} \mathrm{Hg}_{0.8} \mathrm{Te}(a)$ and $(p=n)-\mathrm{Cd}_{0.2} \mathrm{Hg}_{0.8} \mathrm{Te}(b)$. 
occurs between the two adjacent regions with different Young's moduli. Such a region is formed as a result of inhomogeneous deformation of the crystal and with the aim of effective dissipation of elastic energy.

\subsection{Fragmentation of Structure and Interfacial Interaction of Structural Elements of Deformation during Uniaxial Deformation of $\mathrm{Cd}_{x} \mathrm{Hg}_{1-x} \mathrm{Te}$ Crystals}

The problem of the plastic strengthening mechanism and its phasic character was one of the first the dislocation theory of plasticity tried to answer it [15, 16]. However, historically, the mechanism of dislocation strengthening at every stage of the $\sigma-\varepsilon$ curve was studied separately, without connection with other stages, whereas the process of plastic deformation of the crystal presents a continuous process of evolutions of the dislocation ensemble and transition from one stage to another runs smoothly with increasing the degree of plastic deformation.

As a result of comprehensive research, it has been commonly considered that at the first stage of hardening (stage of weak slipping) the dominant mechanism of strengthening is interaction of moving dislocations with boundary dipoles $[15,16]$, and at the second stage, it is their interaction with dislocations of the secondary sets of slipping (dislocations of 'forest') [17, 18]. The third stage is associated with the annihilation of screw dislocations $[17,19]$ and is a stage of dynamic relaxation. At large plastic deformations (of a couple of units), there is a fourth and fifth stage of strengthening; the mechanism of formation of the latter has controversial character at present moment.

However, the traditional description of the plastic deformation of solids is not able to explain the deformation processes at the stages of slight sliding and strain hardening. This approach is based on the known Taylor's scheme that allows ensuring arbitrary changing the form of a crystal with its discontinuity at the action of five steps of sliding. Meanwhile, it has been proved invalidity of the Taylor's scheme: usually the number of actual systems is less than five, and in many cases, sliding occurs predominantly upon one of them. This fact leads to appearance in the deformed crystal of rotational moments of force [2]. As a result, rotational modes and correspondingly higher structural levels of deformation are included in plastic fluidity together with translational slipping. Along with microdeformations (by moving dislocations), it takes place macroplastic fluidity, in which threedimensional structural elements are involved. Thus, in describing the deformation, this problem can be solved only with taking into account the hierarchy of the structural levels of deformation.

The rotational modes of crystal lattice after uniaxial plastic deformation of $\mathrm{Cd}_{x} \mathrm{Hg}_{1-x} \mathrm{Te}$ crystals were revealed by x-ray diffraction in 
[20]. However, a feature of this type of deformation is not only the rotational plastic deformation of the lattice, but also the emergence of new structural elements of deformation. This is supported by any heterogeneity that has stress fields including the accumulation of dislocations, grain boundaries in polycrystals as well as the local areas with enrichment of the suborders in single crystals. Therefore, the carriers of plastic deformation in a semiconductor crystal are the defects of different nature that possess the field of internal stresses. The latter is inherent to the defect or is induced by external stresses.

The important aspect of the problem under study is the fact that uniaxial deformed crystal presents a typical non-equilibrium system, which during plastic deformation moves away from the equilibrium state. Therefore, the important problem at analysing the processes of plastic deformation is dissipation of elastic energy. The theory of behaviour of such systems is considered in [10], where the authors showed that, outside the field of stability of thermodynamic branches (corresponding to the equilibrium conditions), it is originated a new type of arrangement with formation of radically new structures, which strongly differ from the equilibrium ones predictable by classical thermodynamics. Such structures are known to be called as dissipative. Their appearance is a reflection of attempt of the non-equilibrium system to ordering, but not by the Boltzmann's law, but because of the fluctuations that are stabilized at the expense of exchanging the energy with environment. In the deformed crystal, accumulation of deformation defects gives rise to the Bénard's instability (similar to the Bénard's cell in a heated liquid), to formation of new dissipative structures and to transition from deformation by the movement of individual defects to the macroscopic movement of new structural elements.

New types of dissipative structures were observed in $\mathrm{Cd}_{x} \mathrm{Hg}_{1-x} \mathrm{Te}$ deformed crystals with using the selective dislocation etching. In particular, after a small deformation (after fluidity tooth $\varepsilon 2-2.5 \%$ ), the macrodefects of spherical type with concentric lines of dislocation

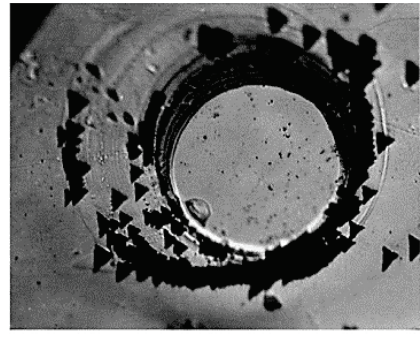

$a$

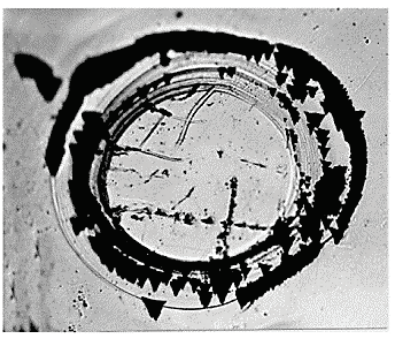

b

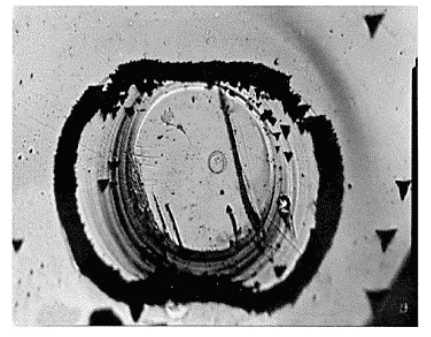

Fig. 5. Regions of local deformation of the crystal by twisting and concentric lines of dislocation slipping detected by selective etching $(a-c)(\times 200)$. 
slipping and etching holes (Fig. 5) are observed. Observation of the set of selective pictures with such defects shows that they are randomly located and do not overlap with each other. General view of such structures indicates that in the vicinity of certain spherical range of the crystal lattice there occurs the plastic deformation of the lattice by its 'screwing' around the axis perpendicular to the plane of the crystal with the circular generation of dislocations.

At the stages of strain hardening ( $\varepsilon \cong 3-5 \%)$, along with the traditional dislocation lines of slipping, the fragmentation of dislocation structure in the form of cells of regular geometric shape adjacent to each other by means of boundaries of dislocation nature is observed (Fig. 6).

A similar cellular dislocation structure was observed in uniaxial deformed crystals $\mathrm{Si}$ [1] and locally deformed $\mathrm{NaCl}$ [21] as a means of relaxation of mechanical stresses near their hubs. According to the Sarafanov's theory [22], formation of such a specific dislocation structure is a result of the specific evolution of the synergetic structure with the aim to minimize the energy of interacting structurally-deformation elements and effective dissipation of elastic energy.

The dislocation fragments are microareas with transverse dimensions of $0.2-0.3 \mathrm{~mm}$, which are strongly disoriented during the plastic deformation. The fragments are deformed uniformly without dislocation formations of bands of cluster type or inhibited bands of shift. At the boundaries of fragments, micronibs and other morphological features are absent that indicate the inhomogeneous realization of plastic deformation in them. Since the typical disorientation between the fragments amounts to tens degrees, the interfragment boundaries are the boundaries of an intergrain type. Therefore, in these regions, the substantial uncompensated densities of dislocations are located, and,
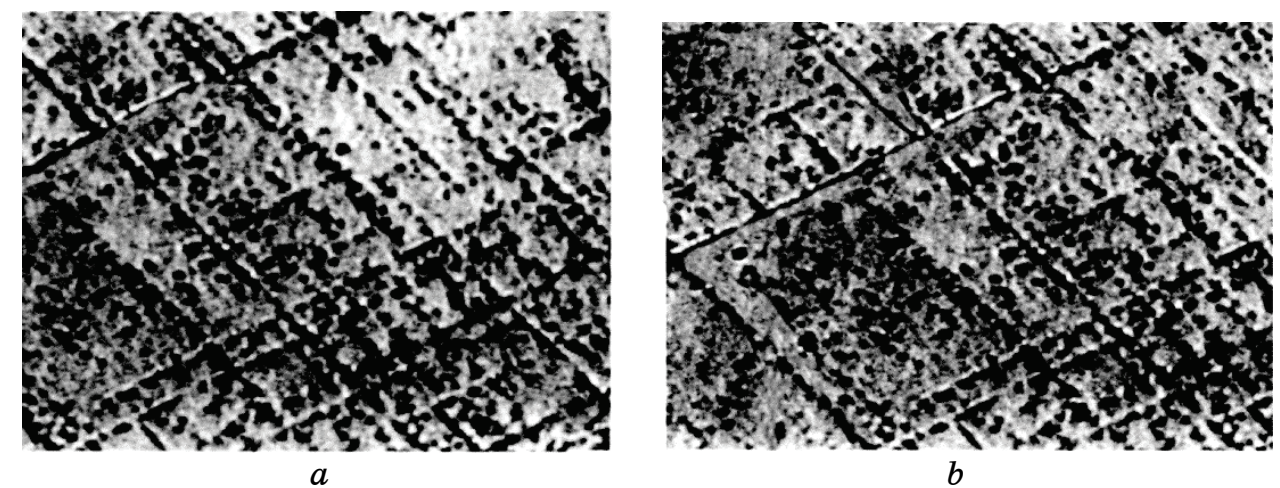

Fig. 6. Example of cellular structure of $\mathrm{Cd}_{0.2} \mathrm{Hg}_{0.8} \mathrm{Te}$ crystal after plastic deformation at the stage of $L_{2}(\varepsilon \cong 4.5 \%)$ revealed by selective etching $(\times 200)$. 
at joints, joint disclinations, so, they are a source of considerable stress. At reaching the stress equal to (1.0-1.9) $G$ ( $G$-shear modulus), the origination of cracks with a typical size of $100 \AA$ is probable.

Studying the phenomenon of fragmentation has revealed that its prime cause is the powerful elastic stresses whose sources arise at the intergrain boundaries and their joints. Actually, the fragmentation is the result of plastic accommodation, which is heterogeneous in the bulk of the grain and is manifested as a fragmented substructure. In the vicinity of joints or morphological features of output (steps, protrusions, speeches, bends), it is observed the emergence of new boundaries that grow inside the grain and divide them into disoriented crystal elements. The driving force of this process is the internal stresses and their sources (plastic incompatibilities) are accumulated at the boundaries due to the difference in the intrinsic plastic deformation of adjacent grains. Their appearance is inevitable since the crystalline subgrains are oriented differently with respect to the macroscopic deforming stresses and therefore exhibit different plastic compliance. However, when the disorientation between the arisen fragments increases, the above-described process is already reproduced at their boundaries and joints, creating a new generation of fragments, and so on.

The homogeneous orientation of the lattice within the structural elements is unstable with respect to the plastic deformation and the fragmentation process is endless (continuous). An important role in the fragmentation of the crystal lattice during the formation of submicrocrystalline structure belongs to the dislocation-disclination mechanism of reorientation of the crystal, which includes the formation of the above sub-structures with high excess density of dislocations of the same sign and its subsequent adjustment in the localized boundary disorientation [23].

Therefore, the fragmented substructure is a structure of mutually disoriented regions (subgrains) separated by small angle and medium angle subboundaries (walls of fragments).

Hence, stage 3 can be represented in a model as a complex structure that includes: 1) the 'debris'-layer formed in the previous stage of pseudo-elastic deformation in the near-surface areas of the crystal (1) and interacting by means of interphases with the bulk of the crystal; 2) the locally-fragmented cells within the bulk of the crystal (2) disoriented relative to each other at certain angles and having different moduli $E_{1}, \ldots, E_{n}$ (Fig. 7).

Therefore, behaviour of the loading diagram is determined by the interaction of two types: 1) between the 'debris'-layer which has the highest Young's modulus (for $\mathrm{Cd}_{0.2} \mathrm{Hg}_{0.8} \mathrm{Te}$ according to the data presented in Fig. 7) and the bulk of the deformed crystal; 2) directly between the above-described local cells of the fragmented structure in the crystal bulk. 

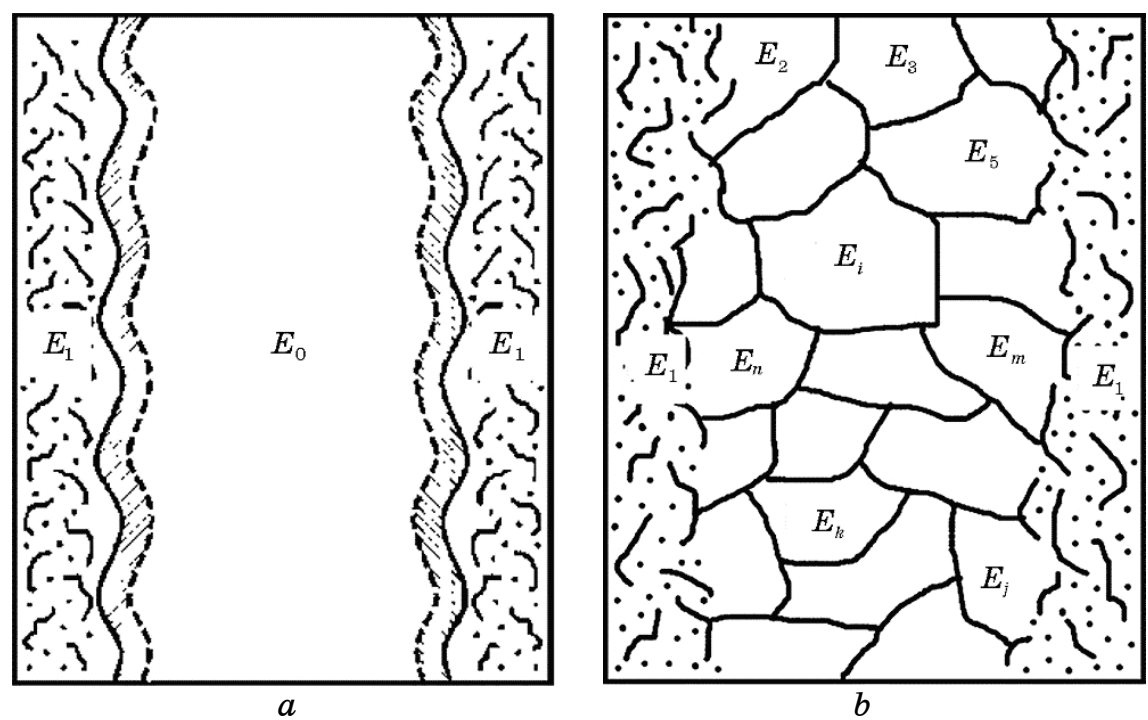

Fig. 7. Model presentation of interactive elements-'debris'-layer and bulk of the crystal at the stage of pseudo-elastic deformation $(a)$; scheme of local fragmentation of the deformed crystal with regions characterized by different Young's moduli $(b)$.

\subsection{Evaluation of Energy Parameters Interfacial Interaction}

Having been formed in the non-equilibrium conditions, the interfacial boundaries are the source of internal mechanical stresses and the region of localization of charges and point defects. However, despite of its importance, the problem of interfacial interaction in the system 'solids (1)-solids (2)' has been not studied by now. The manuscript [24] is a certain contribution to this problem where separated data for some structure are presented. A new approach to solve this problem is proposed in works $[18,19,25,26$, $]$ on the basis of fundamental equations of physics of surface and mechanics of solids.

Let us estimate the energy parameters of interfacial interactions between the above-described deformation-induced fragments in CdHgTe crystals similarly to [27, 28]. We consider energy parameters such interaction, as they determine the degree of elastic interaction at the boundaries of fragments. The obtained data for CdHgTe are desirable to be compared with similar parameters for the crystals with an alternative type of chemical bond such as $\mathrm{Si}, \mathrm{NaCl}$ where dislocationdeformation fragmentation of the structure was revealed [1, 21]. For this purpose, we used the following numerical data:

1) a) $\mathrm{CdHgTe}$ (bulk): $\sigma_{h}(\mathrm{HgTe})=0.352 \mathrm{~N} / \mathrm{m}, \gamma(\mathrm{HgTe})=0.352 \mathrm{~J} / \mathrm{m}^{2}$, $E_{0}(\mathrm{HgTe})=50.1 \mathrm{GPa}, v=0.393$; 
b) 'Debris'-layer CdHgTe: $\sigma_{h}(\mathrm{HgTe})=0.493 \mathrm{~N} / \mathrm{m}, \gamma(\mathrm{HgTe})=0.493$ $\mathrm{J} / \mathrm{m}^{2}, E_{0}(\mathrm{HgTe})=281 \mathrm{GPa}, v=0.393$;

2) $\mathrm{Si}: \sigma_{h}(\mathrm{Si})=1.355 \mathrm{~N} / \mathrm{m}, \gamma(\mathrm{Si})=1.182 \mathrm{~J} / \mathrm{m}^{2}, E_{0}(\mathrm{Si})=138 \mathrm{GPa}, v=$ $=0.27$;

3) $\mathrm{NaCl}: \sigma_{h}(\mathrm{NaCl})=0.366 \mathrm{~N} / \mathrm{m}, \gamma(\mathrm{NaCl})=0.317 \mathrm{~J} / \mathrm{m}^{2}, E_{0}(\mathrm{NaCl})=$ $=37.02 \mathrm{GPa}, v=0.245$.

It should be noted that, at $E=E_{0}$ (equality of Young's moduli for the two neighbouring grains at the absence of external deformation), the calculated values of interfacial energy and interfacial tension of the interacting regions are close to the values of similar parameters of interfacial boundaries $\gamma_{m d}, \sigma_{m z}$, what indicate the validity of the technique used.

Figure 8 shows the results of calculations of the energy parameters of interaction of deformation fragments depending on the ratio of Young's moduli.

We single out the following peculiarities of this interaction. 1) The energy of interfacial interaction and interfacial tension between the deformation fragments of all of the objects under study increases within the range of given modulus changes in contacting fragments (1-1.5) $E_{0}$. The largest changes (and the largest absolute values) of these parameters are observed in crystals $\mathrm{Si}$, and the smallest - in $\mathrm{NaCl}$, respectively (relative changes according to Fig. 8 and Table 1). 2) $\mathrm{NaCl}$ (ionic bond) and $\mathrm{Si}$ (covalent) crystals according to Fig. 8 form the range to which the crystals of $\mathrm{CdTe}-\mathrm{HgTe}$ solid solution belong, having a mixed type of chemical bond (60\% of the ionic component). That is why, on the basis of the studied parameters (and generally on the mechanical properties), they 'tend' to purely ionic crystals of the $\mathrm{NaCl}$ type. 3) In the crystals of mercury chalcogenides, the both parameters of interfacial interaction options for interacting structural levels 'debris'-layer-bulk of the deformed crystal have larger values as compared

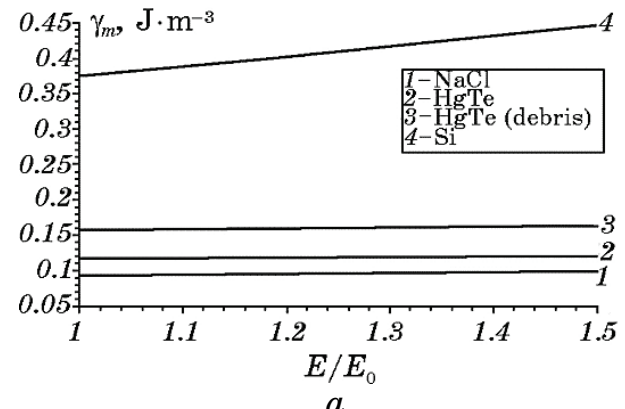

$a$

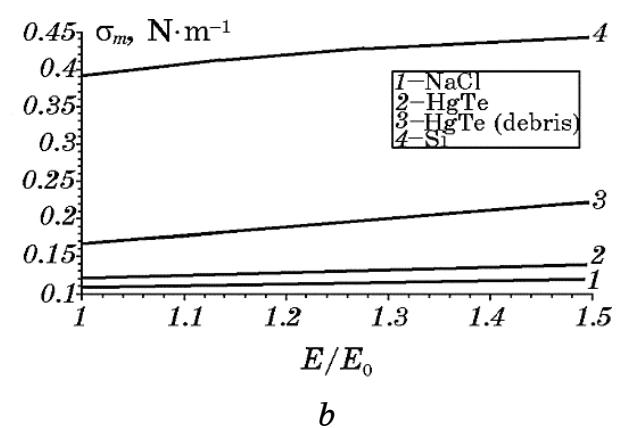

$b$

Fig. 8. Dependence of the energy of interfacial interaction on the ratio of Young's moduli of contacting regions $(a)$; dependence of interfacial tension on the ratio of Young's modulus of contacting regions $(b)$. 
to similar values corresponding to interaction of the bulk fragments.

Thus, the results of studies carried out allow us to make the following conclusions: 1) the magnitude of interfacial interaction between the same type of materials with different moduli is determined by the type of chemical bond; 2) the change in $\sigma(\varepsilon)$ at pseudo-elastic stage is due to the two components: a) the long-range elastic fields of dislocation network 'debris'-layer-bulk of deformed crystal'; b) interfacial interaction (interfacial tension $\theta$ ) in the system 'debris'-layer-bulk'; 3 ) the biggest interfacial tension in the system 'debris'-bulk corresponds to the upper limit of the 'fluidity tooth' $\left.\sigma_{v 0} ; 4\right)$ in the analysed crystals under increasing the covalent component from the pure ionic bond to covalent one, there takes place an increase of the energy parameter of interfacial interaction; 5) the coefficient of strain hardening $d \sigma / d \varepsilon$ is proportional to the parameters $\sigma_{m}$ and $\gamma_{m}$ (see Table 1);6) of the two analysed parameters of interfacial interaction, more sensitive one to changes in moduli is interfacial tension (Table 1), that parameter mainly determines the stress state at interfacial surfaces and the degree of strain hardening during uniaxial loading; 7) at the stage of strain hardening of the diagram $\sigma(\varepsilon)$, the loading process is accompanied by transformation of the dislocation structure in the fragmented (cellular) one and their interfacial interaction what is quantitatively described by the energy parameters of interfacial interaction. Therefore, the course of the loading diagram $\sigma-\varepsilon$ at the stage of plastic deformation is the result not only of reproduction and interaction of dislocations generated by certain laws during the plastic fluidity of the crystal, but also some interfacial interactions between of the deformation fragments.

TABLE 1. Energy parameters of deformation-induced interfacial interactions in crystals with different types of chemical bonds.

\begin{tabular}{|c|c|c|c|c|c|c|c|}
\hline No. & Crystal & $\begin{array}{l}\text { Interacting } \\
\text { fragments }\end{array}$ & $\underset{\%}{\Delta \gamma_{m} / \gamma_{m},}$ & $\underset{\%}{\Delta \sigma_{m} / \sigma_{m},}$ & $\theta_{1}$ & $\begin{array}{c}\text { Type of } \\
\text { chemical } \\
\text { bond }\end{array}$ & $\begin{array}{l}\sigma_{0} \\
\mathrm{MPa}\end{array}$ \\
\hline 1 & $\mathrm{NaCl}$ & Bulk & 4.0 & 9.0 & 0.188 & Ionic & 3 \\
\hline 2 & $\mathrm{Si}$ & $\begin{array}{c}\text { Bulk } \\
\text { 'Debris'-bulk }\end{array}$ & $\begin{array}{l}20 \\
28\end{array}$ & $\begin{array}{l}15 \\
42\end{array}$ & 0.612 & Covalent & 50 \\
\hline 3 & $\mathrm{HgTe}$ & Bulk & 2.0 & 11.5 & 0.288 & $\begin{array}{l}\text { Ionic- } \\
\text { covalent }\end{array}$ & 12 \\
\hline 4 & CdHgTe & $\begin{array}{c}\text { Bulk } \\
\text { 'Debris'-bulk }\end{array}$ & $\begin{array}{l}2.0 \\
2.5\end{array}$ & $\begin{array}{l}13 \\
33\end{array}$ & 0.242 & $\begin{array}{l}\text { Ionic- } \\
\text { covalent }\end{array}$ & 43 \\
\hline 5 & CdTe & Bulk & - & - & 0.088 & $\begin{array}{l}\text { Covalent- } \\
\text { ionic }\end{array}$ & 38 \\
\hline 6 & $\mathrm{Ge}$ & Bulk & 24 & 35 & 2.7 & Covalent & 35 \\
\hline
\end{tabular}


From this point of view, let us analyse some features of strain hardening of crystals with different types of chemical bond, which are realized in the loading curves $\sigma-\varepsilon$. Figure 9 shows the averaged strain curves for some crystals. It follows from the presented dependences that the limit of fluidity increases from purely ionic to covalent crystals. Moreover, as seen from this Figure, the ionic crystals demonstrate 'fluidity tooth' increasing the covalent component in $(\mathrm{HgTe}$, $\mathrm{CdTe}$ ) the limit of fluidity goes up, however the above-mentioned peculiarity is not manifested. The largest values of $\sigma_{0}$ are realized, as expected, in covalent crystals $\mathrm{Si}$, Ge. At the same time, crystals with mixed type of chemical bond belong to intermediate range and the presence of covalent component in $\mathrm{CdHgTe}(\cong 50 \%)$ leads to formation of the 'fluidity tooth'.

The most important result is an increase of the coefficient $\theta_{2}$ with increasing the covalent component (Table 1) that reaches the maximum value in covalent crystals $\mathrm{Si}$ and Ge. Besides, it is seen the linear correlation between the coefficient $\theta_{2}$ and interfacial tension $\sigma_{m z}$, calculated for two neighbouring regions with different Young's moduli $\left(E / E_{0}=\right.$ $=1.5$ ) (Fig. 10).

Hence, covalent crystals, which are the most susceptible to deformation fragmentation, show the greatest interfacial tension, and consequently should also possess the largest coefficient of strain hardening that is observed in the experiment.

Thus, attempt to create the effective dissipative structures during loading process gives rise to inclusion, besides dislocation level, other

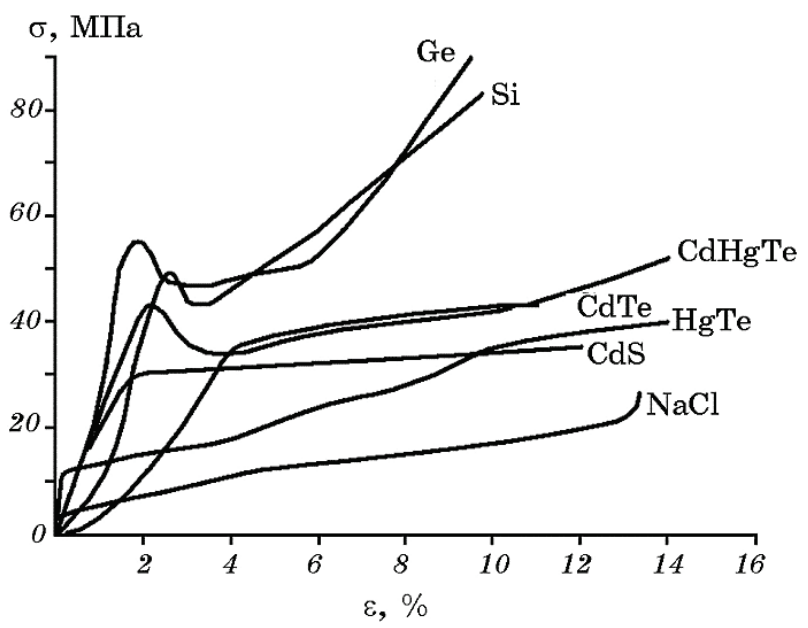

Fig. 9. Typical diagrams of loading for crystals having different types of chemical bonds (orientation $-<100>, V=5.85 \cdot 10^{-3} \mathrm{~mm} / \mathrm{min}, T=300 \mathrm{~K}$; temperature of deformation: $\mathrm{Si}-750 \mathrm{~K}, \mathrm{Ge}-550 \mathrm{~K})$. 
ones of strain, in particular with using structural interacting fragments and other macrodefects of a crystal. Therefore, the curve $\sigma(\varepsilon)$ reflects to a large extent just the stage of formation of dissipative structures.

In particular, the stage of weak slipping causes rotary moments of force, but their action is limited mainly by the sample's regions in the vicinity of clips. When their influence extends to the active region of the sample, there is initiated multiple slipping that performs the crystallographic rotation. The rapid accumulation of dislocations at this stage of deformation causes the appearance of the shear instability in clusters of dislocation and formation of dislocation substructure as a dissipative system. Transition to macromovement of the substructure elements, as a whole, gives rise to abrupt intensification of plastic fluidity and efficient dissipation of elastic energy of the deformed crystal.

The dissipative structure character depends on the shear stability of the initial crystal and conditions of its deformation. As shown in [2], in the case of shear-proof crystals, the dissipative structure at dislocation mechanism of slip looks like a cellular structure. At low temperatures and high rates of strain, it is possible to create in the lattice strong collective displacements of atoms at hard formation of the dislocation substructure. The nature of this process consists in the structural phase transition, usually in the form of deformation twins. At these conditions, the dissipative structure is formed as deformation twins in non-equilibrium lattice with large displacement of atoms from the lattice sites. As a confirmation of that, we have observed the twin layers in $\mathrm{CdHgTe}$ crystals during their deformation at nitrogen and higher temperatures. Moreover, the concentration of twins decreases with increasing the temperature, and under deformation at the room

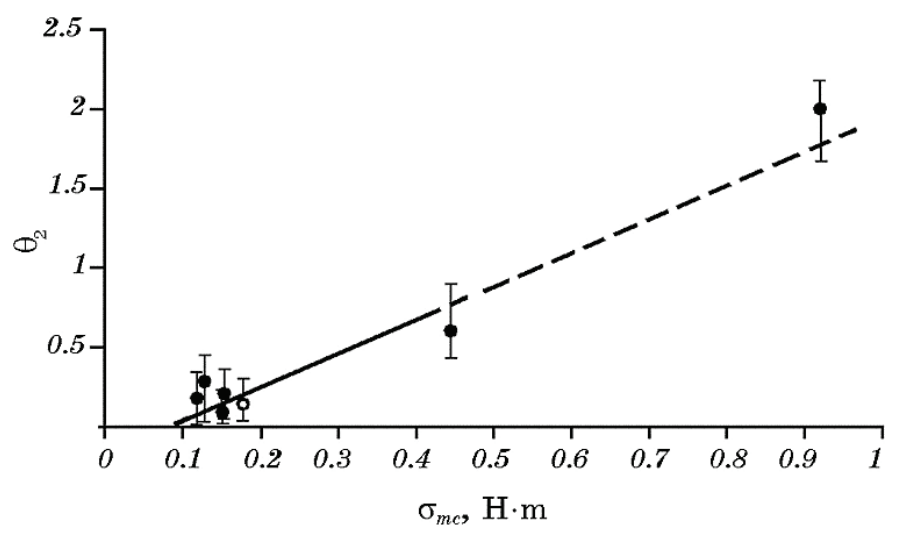

Fig. 10. Dependence of the coefficient of strain hardening $\theta_{2}$ (section $L_{2}$ in the diagram $\sigma-\varepsilon$ ) on the interfacial tension of boundaries of deformation fragments in crystals with different types of chemical bond. 
temperature, such defects are rare.

Analysis of plastic deformation of crystals on the basis of representation about dissipative structures allows us to understand some features of macrofluidity of solids that do not find justification in the mechanics of deformed solids and exclusively in the dislocation concept of deformation.

\section{CONCLUSIONS}

1. The role of the near-surface layer of uniaxial deformed crystals during their deformation is studied out. It is revealed forming at the pseudo-elastic stage of deformation of CdHgTe crystals the 'debris'layer, which, under subsequent loading of the crystal, serves as a barrier to dislocations generated by 'bulk' sources.

2. It is found out that deformation of CdHgTe crystals, along with the translational dislocation slipping, is accompanied by the rotational component of the lattice strain and the emergence of new structural elements of the strain, which independently take part in the deformation process. New types of dissipative structures, which ensure the most efficient dissipation of elastic energy at this stage of deformation of the crystal, are revealed.

3 . The role of interfacial interactions in the formation of elastic-plastic state of single crystals of semiconductors is clarified. It is revealed the phenomenon of deformation-induced interfacial interaction, which is realized in the crystals deformed uniaxially at a constant rate: 1 ) at the pseudo-elastic stage of the loading diagram as a result of interfacial interaction between the 'debris'-layer and bulk of the crystal; 2) at the stage of strain hardening between deformation fragments with different Young's moduli $\left(E_{1}, \ldots, E_{n}\right)$, which arise in the deformed crystal.

4. The loading process of a crystal at the stage $\left(L_{2}\right)$ of strain hardening in the diagram $\sigma(\varepsilon)$ is accompanied by transformation of the dislocation structure in the fragmented form and by internal interfacial interaction that quantitatively described with the energy parameters: $\sigma_{h}(\mathrm{CdHgTe})=0.493 \mathrm{~N} / \mathrm{m}, \gamma_{h}(\mathrm{CdHgTe})=0.493 \mathrm{~J} / \mathrm{m}^{2}$. It is found out the correlation of 'coefficient of strain hardening-interfacial tension' between the deformation fragments in the bulk of the crystal.

\section{REFERENCES}

1. V. P. Alekhin, Physics of Strength and Plasticity of Surface Layer Materials (Moscow: Nauka: 1983 ) (inRussian).

2. V. E. Panin, Yu. Grinyaev, and V. I. Danilov, Structural Levels of Plasticity Deformation and Fracture (Novosibirsk: Nauka: 1990) (in Russian).

3. V. E. Egorushkin, V. E. Panin, and A. V. Panin, Physical Mesomechanics, 17, No. 2: 19 (2014) (in Russian). 
4. P. V. Makarov, Theor. Appl.Fracture Mech., 33, No. 1: 23 (2000).

5. L. L. Meisner, V. P. Sivokha, A. I. Lotkov, and L. A. Derevyagina, Physica B, 1-4, No. 307: 251 (2001).

6. Physical Mesomechanics of Heterogeneous Media and Computer-Aided Design of Materials (Ed. V. E. Panin) (Cambridge: Cambridge Interscience Publishing: 1998).

7. V. V. Neverov and P. P. Zhitnikov, Phys. Met. Metallogr., 43, No. 1: 143 (1990) (in Russian).

8. T. V. Tretyakova and V. E. Widemann, Fract. Struct. Integr., 27: 83 (2014).

9. N. A. Koneva, D. V. Lychanin, and S. P. Zhukovsky, Phys. Met. Metallogr., 60, No. 1:171 (1985) (in Russian).

10. G. Nikolis and I. Prigogine, Self-Organization in Non-Equilibrium Systems (Moscow: Mir: 1979) (Russian translation).

11. B. P. Koman, Physics and Chemistry of Solid State, 12: 1018 (2011) (in Ukrainian).

12. V. I. Trefilov and Yu. V. Milman, Dokl. AN SSSR, 153, No. 4: 824 (1963) (in Russian).

13. V. I. Trefilov and Yu. V. Milman, Problems of the Physics of Metals and Metal. Coll.: Scientific Works of the Institute for Metal Physics, Academy of Sciences of the Ukrainian S.S.R.), 17: 32 (1963) (in Russian).

14. A. Ivens and R. Rowling, Thermally Activated Processes in Crystals (Moscow: Mir: 1973), p. 172 (Russian translation).

15. F. R. N. Nabarro, Z. S. Basinski, and D. Holt, Plasticity of Pure Single Crystals (Moscow: Metallurgy: 1967) (Russian translation).

16. B. I. Smirnov, Dislocation Structure and Hardening of Crystals (Moscow: Nauka: 1981) (in Russian).

17. U. F. Koks, A. S. Argon, and M. F. Ashby, Thermodynamics and Kinetics of Slip (New York: Pergamon Press: 1975).

18. S. J. Basinski and Z. S. Basinski, Dislocation in Solids (Amsterdam: North-Holland: 1979), vol. 4.

19. G. A. Maligin, Phys. Solid State, 35, No. 6: 1609 (1993).

20. I. V. Kurilo and I. S. Osypyshyn, Vistn. Lviv Polytechn. Institute Electron. Technics and Appliances, 32: 89 (1979) (in Ukrainian).

21. M. A. Volosyuk, Relaxation of Mechanical Stresses in Crystalline Solids with F.C.C. Lattice ( $\mathrm{Cu}, \mathrm{NaCl}, \mathrm{KCl}$ ) Near Stress Concentrators (Thesis of Disser. for Cand. Phys.-Math. Sci.) (Kharkiv: 2014) (in Ukrainian).

22. G. F. Sarafanov, Fundamentals of the Kinetic Theory of the Formation of Structures Disoriented During Plastic Deformation of Metals (Nizhniy Novgorod: N-NSU: 2011) (in Russian).

23. I. A. Ditenberg, A. N. Tyummentsev, K. V. Grynyaev, V. M. Chernov, M. M. Khotapenko, and A. V. Korznikov, Technical Physics, 56, No. 6: 815 (2011) (in Russian).

24. V. Myssol and W. Missol, Surface Energy of the Phase Separation in Metals (Moscow: Metallurgy: 1978) (in Russian).

25. P. M. Soprunjuk and V. M. Yuzevych, Diagnostics of Materials and Environments. Energetic Characteristics of Surface Layers (Lviv: Spolom: 2005) (in Ukrainian).

26. B. P. Koman and V. M. Yuzevych, Fizika Tverdogo Tela, 54, No. 7: 1335 (2012). 
27. B. P. Koman and V. M. Yuzevych, Metallofiz. Noveishie Tekhnol., 36, No. 8: 1113 (2014) (in Ukrainian).

28. V. M. Yuzevych and B. P. Koman, Metallofiz. Noveishie Tekhnol., 25, No. 6: 747 (2003) (in Ukrainian). 